\title{
LITHOGENESIS OF MONOGENIC (BAR) SANDSTONES OF THE KAMENSKAYA SUITE MIDDLE CARBONIFEROUS $\left(\mathrm{C}_{2}{ }^{5}\right)$ OF THE DONETS BASIN
}

\author{
K.M. Sedayeva
}

\section{ЛИТОГЕНЕЗ МОНОГЕНЕТИЧЕСКИХ (БАРОВЫХ) ПЕСЧАНИКОВ КАМЕНСКОЙ СВИТЫ СРЕДНЕГО КАРБОНА $\left(\mathrm{C}_{2}{ }^{5}\right)$ ДОНЕЦКОГО БАССЕЙНА}

\author{
К.М. Седаева
}

For the first time, proceeding from detailed mineralogical and petrographic investigations of bar sandstones of the Dnieper-Donets Basin the author demonstrates irregularities of their postdiagenetic transformations during various stages of lithogenesis. During the catagenesis stage, new mineral forms prevails in cementing mass of the sandstones over structural ones. During the metagenesis stage the role of structural transformations increases sharply. The character and grade of these transformations depends upon the structure, composition, and quantitative relations between initial components both of clastic and cementing masses of the sandstones themselves. Key words: lithogenesis, catagenesis, metagenesis, sandstones, Donets Basin.

Впервые на основе детального минерально-петрографического изучения баровых песчаников Донецкого бассейна с применением стадиального анализа выявлена неравномерность их постдиагенетических изменений на различных стадиях литогенеза. На стадии катагенеза преобладают минеральные новообразования в цементирующей массе песчаников над структурными. На стадии метагенеза, наоборот, резко возрастает роль структурных преобразований над минеральными. Характер и степень этих преобразований зависят от структуры, состава и количественного соотношения между собой исходных компонентов как обломочной, так и цементирующей массы самих песчаников.

Ключевые слова: литогенез, катагенез, метагенез, песчаники, Донецкий бассейн.

\section{ВВЕДЕНИЕ}

Внутри многокилометровой толщи угленосных отложений среднего карбона Донецкого бассейна прослеживаются уровни накопления мелкообломочных пород значительной мощности от 10-15 до 30-40 и реже до 60 м. Максимальная концентрация мелкообломочных пород среди угленосных свит Донбасса отмечается в разрезах каменской свиты $\left(\mathrm{C}_{2}{ }^{5}\right)$, возраст которой по фораминиферам, конодонтам и другим органическим остаткам отвечает верхам верхнебашкирского и низам нижнемосковского подъярусов среднего карбона. Мелкообломочные породы представлены, в основном, песчаниками, реже алевролитами и крайне редко гравелитами с незначительной примесью мелкой гальки. Песчаники полимиктовые, характеризуются более или менее одинаковым составом обломочной части и относятся, по классификации А.Г. Коссовской и В.Д. Шутова [Граувакки, 1972], в основном, к полевошпат-кварцевым грауваккам. Среди них встречаются разности, обогащенные слюдами и полевыми шпатами вулканогенной природы и относящиеся к кварц-полевошпатовым грауваккам. Полевошпат-кварцевые и кварц-полевошпатовые граувакки содержат менее 40\% зерен кварца, их обломочный материал является менее зрелым. Это косвенно свидетельствует о том, что размывались породы, слабо затронутые процессами выветривания, и что они накапливались в предшествующие эпохи формирования внутриконтинентального рифтового прогиба, возникшего в начале позднего палеозоя на южной окраине Восточно-Европейской платформы. Среди мелкообломочных пород наиболее значимыми являются (снизу вверх) «табачковые», «лисьи» и «рубежные» песчаники, название которых были даны донецкими геологами, и они укоренились в научной литературе.

Горизонт «табачковых» песчаников (мощностью 25-35 м) стратиграфически приурочен к верхам верхнебашкирского подъяруса. Он залегает в интервале разреза между пластами известняков $\mathrm{K}_{1}$ и $\mathrm{K}_{2}$ и обозначается индексом $\mathrm{K}_{1} \mathrm{SK}_{2}$. Песчаники серые или темно-серые с характерным зеленоватым оттенком, средне- и крупнозернистые (в нижней половине), однородные или слоистые (в нижней и верхней трети их разреза), с редкой параллельной слоистостью за счет скопления мелкой гальки и дресвы глинистых пород, крупных фрагментов растений (внизу) иногда вместе со слюдой или мелких растительных остатков (вверху) по наслоению. По составу они полимиктовые, граувакковые, в той или иной мере слюдистые, преимущественно литокластово-кварц-полевошпатовые.

Горизонт «лисьих» песчаников (мощностью от 18-30 до 40 м) залегает в основании нижнемосковского подъяруса, в интервале разреза свиты между пластами известняков $\mathrm{K}_{3}$ и $\mathrm{K}_{4}$ и имеет индекс 
$\mathrm{K}_{3} \mathrm{SK}_{4}$. Песчаники светло-серые, среднезернистые, в основании грубо- крупно-, а в кровле - мелкопсаммитовые, с нечеткой косой и отчасти горизонтальной (вверху) слоистостью за счет скопления мельчайших растительных остатков и слюды нередко вместе с зернами сидерита по наслоению. По составу они полимиктовые, граувакковые, литокластово-полевошпат-кварцевые, на отдельных интервалах разреза сильно слюдистые, переходя в кварц-полевошпат-слюдистые граувакки.

Горизонт «рубежных» песчаников (мощностью от 15-25 до 60 м) стратиграфически приурочен к верхам нижнемосковского подъяруса. Он залегает в интервале разреза между пластами известняков $\mathrm{K}_{9}$ (каменской свиты) и $\mathrm{L}_{1}$ (алмазной свиты $\mathrm{C}_{2}{ }^{6}$ ) и обозначается индексом $\mathrm{K}_{9} \mathrm{SL}_{1}$. Песчаники светлосерые, грубо- и толстослоистые в разрезе, среднезернистые, в основании крупно-, а в кровле алеврито-мелкопсаммитовые, с маломощными мелкогалечно-гравийными прослоями в подошве и на отдельных интервалах их разреза. По составу они полимиктовые, граувакковые, литокластово-полевошпат-кварцевые, слабо слюдистые.

Исследования состава породообразующих компонентов $[3,8,10]$ мелкообломочных пород и комплекса акцессорных минералов (минералов тяжелой фракции) показали более или менее их одинаковый состав, они содержат один и тот же набор породообразующих компонентов и акцессорий, отличаясь только количественным их содержанием. В обломочной части песчаников отмечаются обломки пород (литокластов), минералов (кристаллокластов) и кварца. Среди литокластов присутствуют обломки: 1) эффузивных пород среднего и кислого состава; 2) метаморфических пород - кварцитов и различных сланцев (глинистых, биотито-кварцевых, хлорито-кварцевых, мусковито-кварцевых, слюдистых в «рубежных» песчаниках) или (кварцево-хлоритовых, кварцево-слюдистых, кварцевобиотитовых, глинистых сланцев в «табачковых» песчаниках), и 3) осадочных пород - силицитов кварц-халцедонового состава с редкими радиоляриями (крайне редко, в юго-восточной части Донбасса), известняков, алевролитов и аргиллитов. Кристаллокласты представлены плагиоклазами среднего и кислого состава, различными слюдами и др. Количественное соотношение между всеми вышеперечисленными обломками непостоянно и изменяется без какой-либо закономерности как по площади, так и по разрезу. Общее количество акцессорий не превышает 0,3-0,7\% и их распределение по разрезу и на площади не имеет коррелятивного значения. В их составе отмечаются следующие минералы тяжелой фракции: турмалин, пирит, сидерит, роговая обманка, эпидот, андалузит или дистен, ставролит, циркон и апатит. Относительная близость компонентного состава обломочной части песчаников и почти неизменяющийся состав комплекса их акцессорных минералов свидетельствуют о неизменности области питания на протяжении накопления отложений каменской свиты [2].

Впервые данные о баровой природе данных горизонтов мощных песчаников каменской свиты были представлены А.Н. Волковой, Н.В. Ивановой и А.М. Пиотровским в конце семидесятых годов прошлого столетия. Позднее А.М. Пиотровским были проведены литолого-палеогеоморфологические исследования мощных горизонтов песчаников и на большом фактическом материале, полученном при бурении многочисленных скважин в различных геолого-промышленных районах Донецкого бассейна, было установлено по ряду геоморфологических признаков, что это баровые песчаники. Исходя из общих черт палеогеографии и почти повсеместного распространения данных песчаников, однотипных по строению и составу $\left(\mathrm{K}_{1} \mathrm{SK}_{2}, \mathrm{~K}_{3} \mathrm{SK}_{4}\right.$ и $\left.\mathrm{K}_{9} \mathrm{SL}_{1}\right)$, можно отметить, что они являются отложениями островных баров (барьерных островов) и пляжей. Их возникновение, вероятнее всего, связано с перемывом песчаных осадков фронта дельты (или системы дельт) и береговой линии. Аналогичные горизонты мощных песчаников среди угленосных формаций различного палеозойского возраста широко распространены по окраинам древних платформ [11].

\section{ФАКТИЧЕСКИЙ МАТЕРИАЛ И МЕТОДИКА ИССЛЕДОВАНИЯ}

Исследование песчаников каменской свиты среднего карбона происходило в три этапа. На начальном этапе исследования проводился детальный литолого-фациальный анализ. Были изучены разрезы и построены профили мощных горизонтов песчаников от платформенного склона Восточно-Европейской платформы, где породы наименее преобразованы (начальный катагенез, угли марки «Д») до осевой части Донецкого прогиба (Центральный и Восточный Донбасс), сложенного сильно измененными толщами (до стадии позднего метагенеза, угли марки «А»). В результате применения литолого-фациального анализа и использования ранее опубликованных результатов классических работ по палеогеографии Донецкого бассейна $[2,5,6,7,9]$ и других работ по литологии были уточнены и дополнены их характеристики и подтверждена их баровая природа. 
На втором этапе проводился стадиально-петрографический анализ последовательности формирования и изменения структурно-текстурных и минеральных парагенезисов в песчаниках $\mathrm{K}_{1} \mathrm{SK}_{2}, \mathrm{~K}_{3} \mathrm{SK}_{4}$ и $\mathrm{K}_{9} \mathrm{SL}_{1}$ по стадиям литогенеза и углефикации. Стадиальный анализ постседиментационных структурно-минеральных парагенезисов выполнялся на той же основе и с учетом того, что было ранее сделано в этой области Н.В. Логвиненко [10], Г.Ф. Крашенинниковым и его соратниками [8], А.Н. Волковой и К.М. Седаевой [3], А.Г. Викуловым и К.М. Седаевой [1]. Проводилось определение состава песчаников в результате подсчета большого количества зерен (более 300 ) и состав рассчитывался на $100 \%$. Цементирующий материал обломочных пород также подсчитывался отдельно, компоненты цемента рассчитывались из 100\%. Содержание минеральных и структурных новообразований рассчитывалось на всю породу. Количественный подсчет минеральных и структурных новообразований проводился в пределах каждого основного петротипа мелкообломочных пород. Одновременно выяснялось их количественное распределение и соотношение между петротипами и по разрезу одного и того же горизонта песчаников с учетом зон литогенеза и углефикации и сопоставлялось с данными по другим их горизонтам. Такая последовательность изучения позволила ограничить первичные седиментационные особенности мелкообломочных пород, связанные с их генезисом, от наложенных в катагенезе и метагенезе постседиментационных преобразований, а также выявить их соотношение между собой. На заключительном обобщаемом этапе проводилось последовательное постадийное ранжирование первичных (седиментационных) и вторичных (новообразованных) структур и (аутигенных) компонентов мелкообломочных пород и их типизация по зонам литогенеза и углефикации.

\section{РЕЗУЛЬТАТЫ И ИХ АНАЛИЗ}

Ранний катагенез (угли длиннопламенные - марки Д). Район распространения песчаников, преобразованных до стадии раннего катагенеза, располагается в пределах платформенного склона Восточно-Европейской платформы - на южном склоне Воронежской антеклизы, где угленосные отложения каменской свиты $\left(\mathrm{C}_{2}{ }^{5}\right)$ небольшой (200-220м) мощности слабо дислоцированы. Характерным для района является невысокое содержание песчаников (20\%), залегающих в виде плохо выдержанных на площади пластов и пачек, за исключением мощных их горизонтов $\left(\mathrm{K}_{1} \mathrm{SK}_{2}, \mathrm{~K}_{3} \mathrm{SK}_{4}\right.$ и K $\left.\mathrm{SL}_{1}\right)$.

«Табачковые» песчаники (около 20м) зеленовато-серые с буроватым оттенком, неравномерно зернистые, в основном средне-, реже мелкопсаммитовые (вверху), в меньшей степени крупнозернистые с маломощными прослоями гравийно-мелкощебенчастого материала (особенно в их средней части, на отдельных интервалах и в основании), полого косослоистые за счет скопления мелких растительных остатков по наслоениию. По составу они граувакковые, полевошпат-кварцево-литокластовые, состоящие из обломков измененных эффузивов среднего состава (20-25\%), различных метаморфических пород (от 2527\% в нижней и до 10-15\% в верхней половине их разреза), полевых шпатов (12-18\%), кварца (10-15\%) и слюд (до 2-5\%). Среди метакластов отмечаются обломки кварцево-хлоритовых, слюдистых, кварцевобиотитовых, глинистых сланцев и редко кварцитов. В них встречается пласт мелко-среднезернистого песчаника серовато-зеленого цвета (мощностью около 3,5м), залегающего с размывом. В этом пласте порода обильно (более $50 \%$ общего объема обломков) обогащена свежими плагиоклазами и биотитом, а также обломками эффузивов среднего состава и вследствие этого ее можно отнести к туффитам.

В табачковых песчаниках цемент поровый, гидрослюдисто (2-5\%)-хлоритово (5-10\%)-монтмориллонитовый (10-15\%), в нем наблюдаются рассеянные мелкие пятна гидрооксидов железа и развитие единичных крупных листочков хлорита (придающий породе зеленовато-серый цвет). Его содержание в породе не превышает 15-20\%. На отдельных интервалах разреза песчаников часто наблюдается вторичный кальцитовый цемент - спаритовый порового или порово-базального типа, который замещает участками глинистый цемент и частично корродирует некоторые обломки кварца, реже плагиоклазов. При широком его развитии реликты глинистого цемента нередко сохранились на стенках пор и на поверхности обломочных зерен в виде тончайшей пленки. Образование кальцитового цемента отмечается в мелко-среднезернистых туфогенных и крупнозернистых разностях песчаников с маломощными прослоями гравийно-мелкощебенчастого материала (встречающихся в основании и в их средней части, на отдельных интервалах), формируя пласты и прослои очень крепких песчаников среди умеренно- и среднепрочных их разностей. Минеральные нововообразования очень незначительны. Из аутигенных минералов развиты гидрослюды по биотиту, хлориты и смешаннослойные образования по биотиту и обломкам измененных эффузивов среднего состава 
«Лисьи» песчаники (мощностью 20-22 м) преимущественно светло-серые, иногда почти белые, слабосцементированные, рыхлые, только в отдельных тонких прослоях крепкие, средне-мелкозернистые, среднесортированные, с редкими маломощными (5-7 см) прослоями дресвяно-гравийнокрупнопсаммитового материала, сложенного полуокатанными и окатанными обломками. По составу они граувакковые и в них наблюдаются обломки кварца (18-25\%), измененных эффузивных пород (до 30\%) кислого и реже среднего состава, слюдистых сланцев (7-13\%), кварцитов (8-112\%), полевых шпатов (5-7\%) и слюд (0-7\%).

Цемент (20-25\%) поровый - крупночешуйчатый, каолиновый; в участках скопления зерен эффузивов в нем развит хлоритовый. На отдельных их интервалах наблюдается кальцитовый цемент. Из новообразований развиты гидрослюды (по биотиту), хлориты (по биотиту и обломкам вулканокластов), светлый яснокристаллический кальцит - спарит, а в редчайших случаях наблюдаются участки регенерационного кварца около кварцевых зерен. В маломощных прослоях песчаника с обильным кальцитовым цементом отмечается значительное количество обломков свежих кристаллов плагиоклазов (до $10 \%)$, при общем их содержании полевых шпатов около $20 \%$, а обломков эффузивов $40-42 \%$. Соответственно содержание зерен кварца и кварцитов в них резко падает. Песчаники с высоким содержанием обломков вулканокластов и отчасти свежих зерен плагиоклазов относятся к туфогенным их разностям. Широкое развитие в разрезе слабо сцементированных (рыхлых) разностей песчаников, а также наличие в них каолинового и отчасти регенерационного кварцевого цементов косвенно свидетельствует о возможной «промытости» их подземными палеоводами метеогенной природы.

«Рубежные» песчаники (мощностью 40-42 м) светло-серые и беловато-серые, среднезернистые, состоящие из угловатых, реже полуокатанных зерен, среднесортированные, нечетко косо- или горизонтальнослоистые (в основном вверху), за счет скопления мельчайших растительных остатков, а иногда мелких линзочек глинистого материала. В их основании располагается маломощный гравийный прослой, содержащий рассеянную мелкую гальку местных карбонатных и глинистых пород. По составу они граувакковые и в них отмечаются обломки эффузивов (20-25\%), слюдистых сланцев (10-15\%), кварцитов (8-10\%), полевых шпатов (15-20\%), слюд (от1-2\% в подошве до10\%) и кварца (от 25-20\% в основании и до 15-10\%).

Цемент (20-25\%) в основном пленочно-поровый, глинистый, (гидрослюдистый 10-20\%), местами хлоритово(1-8\%)-гидрослюдистый, с пятнами и участками вторичного кальцита и мелкими агрегатами сидерита. В нижней их части наблюдается обильный кальцитовый цемент. Новообразования неначительны - это прорастание биотита мелкими зернами сидерита, образование тончайших листочков гидрослюды около терригенного мусковита, иногда с образованием мелких пакетов каолинита в порах, и развитие спарита - светлого яснокристаллического кальцита, нередко корродирующего обломки эффузивов, полевых шпатов и отчасти слюдистых сланцев. Из аутигенных минералов наблюдаются кальцит, в меньшей степени сидерит и крайне редко гидрослюда и каолинит.

При минерально-петрографических исследованиях выяснилось, что «рубежные» песчаники $\left(\mathrm{K}_{9} \mathrm{SL}_{1}\right)$ заметно отличаются по составу терригенных компонентов от «лисьих» $\left(\mathrm{K}_{3} \mathrm{SK}_{4}\right)$ и «табачковых» $\left(\mathrm{K}_{1} \mathrm{SK}_{2}\right)$. Отличия отмечаются в количественном содержании обломочных компонентов породы и наличии в двух последних горизонтах песчаниках $\left(\mathrm{K}_{1} \mathrm{SK}_{2}\right.$ и $\left.\mathrm{K}_{3} \mathrm{SK}_{4}\right)$ прослоев и пластов, обогащенных вулканогенным материалом. Маломощные (5-7 см) их прослои отмечаются в «лисьих» песчаниках, но максимальное содержание наблюдается в «табачковых» песчаниках. В «рубежных» песчаниках такие прослои не обнаружены. Они в своем составе содержат более $25 \%$ кварца и относительно много обломков кварцитов; в «лисьих» и «табачковых» песчаниках роль кварца и кварцита несколько ниже. По классификации А.Г. Косовской и В.Д. Шутова песчаники относятся к полевошпат-кварцевым грауваккам, к кварц-фельзит-порфировой их разновидности. «Лисьи» и «табачковые» песчаники, хотя и относятся к тем же подразделениям, но в их составе значительно выше содержание литокластов (различных сланцев и эффузивов среднего и реже кислого состава) и несколько пониженное содержание кварца и кварцитов. Исследования тонкой фракции (меньше 0,001 мм) глинистой составляющей цемента песчаников $\mathrm{K}_{1} \mathrm{SK}_{2}, \mathrm{~K}_{3} \mathrm{SK}_{4}$ и K $\mathrm{K}_{9} \mathrm{SL}_{1}$ показали, что по составу она полиминеральная. В составе значительную роль играют монтмориллониты, гидрослюда, хлориты, в меньшей степени каолинит и крайне редко смешаннослойные образования $[3,8]$. Поскольку первичный обломочный материал песчаников имеет более или менее сходный состав обломков, отличаясь только по количественному их содержанию, то минеральные новообразования на этой стадии литогенеза также имеют много общего. В них отмечается обрастание гидрослюдой терригенных 
слюд, развитие мелкозернистых агрегатов сидерита (по биотиту) и карбонатизации (участками), нередко с образованием обильного вторичного кальцитового цемента, корродирущего иногда обломочные зерна кварца и плагиоклаза. Широко развита и хлоритизация. В ряде случаев, особенно в «лисьих» и «табачковых» песчаниках, где имеется существенная примесь туфогенного материала, хлоритизация является ведущим процессом. Хлорит встречается как в цементе, так и развивается по зернам эффузивов и биотиту. Прослеживается ряд стадий замещения хлоритом терригенного биотита, последний часто бывает гидратирован. Эти процессы особенно характерны для туфогенных разностей песчаников. Регенерация кварца отмечается крайне редко и, возможно, связана с воздействием подземных палеовод метеогенной природы или (и) влиянием древних гипергенных процессов. Смешанослойные образования развиты незначительно и встречены лишь в цементе «табачковых» песчаников.

Таким образом, на стадии раннего катагенеза интенсивность постседиментационных изменений моногенетических (баровых) песчаников достаточно низкая. Литогенетические преобразования проявились в образовании вторичного кальцитового цемента с некоторой коррозией обломочных зерен; в хлоритизации и отчасти гидрослюдизации биотита с образованием мельчайших агрегатов сидерита; в хлоритизации обломков эффузивов среднего состава; гидрослюдизации терригенного мусковита, каолинитизации вулканокластов кислого состава, а также в образовании мелких пакетов каолинита в порах.

Поздний катагенез (угли газовые, жирные, коксовые и отощенно-спекающиеся - угли марки Г, Ж, К и ОС). Район распространения угленосных отложений, преобразованных до стадии позднего (глубинного) катагенеза, приурочен к бортовой части Донецкого прогиба (т.е. бортовой части проторифта) и охватывает в основном юг и юго-восток Центрального Донбасса. Мощность отложений каменской свиты достигает от 420-460 до 575-610 м. Песчаники составляют 22-42\% разреза и это связано с увеличением мощности основных горизонтов песчаников $\left(\mathrm{K}_{1} \mathrm{SK}_{2}, \mathrm{~K}_{3} \mathrm{SK}_{4}\right.$ и $\left.\mathrm{K}_{9} \mathrm{SL}_{1}\right)$ и появления невыдержанных по площади и разрезу пачек и пластов песчаников под угольными пластами k7, k5, k3 .

«Табачковые» песчаники (мощностью около 30 м) темно-серые с зеленоватом оттенком, преимущественно среднезернистые, в нижней половине крупнозернистые, верхней - с редкими прослоями мелкой и тонкой фракций. Песчаники граувакковые, сильно слюдистые, с горизонтальной слоистостью, обусловленной скоплениями мельчайших растительных остатков, дресвы глинистого состава и крайне редко крупных растительных фрагментов (листочков, стеблей или мелких веточек) плохой сохранности. По составу терригенных компонентов они однородны, с небольшим разбросом в содержании тех или иных их обломков. Обломки пород составляют 45-65\%, кварца - 20-32\%, полевых шпатов - 14-25\%. В средней их части увеличивается содержание полевых шпатов (до 35\%). Здесь появляются в небольшом количестве угловатые и призматические зерна кислого плагиоклаза свежего облика, увеличивается содержание обломков эффузивов среднего состава и уменьшается количество обломков метаморфических пород, что, по-видимому, связано с поступлением перемытого вулканогенного материала. Породы всей пачки в целом можно отнести к полевошпат-кварцевым грауваккам, а интервалы, обогащенные плагиоклазами и эффузивами, следует считать уже кварц-полевошпатовыми граувакками.

Песчаники $\mathrm{K}_{1} \mathrm{SK}_{2}$ характеризуются хлоритовым крустификационным цементом, где центральные части заняты кварцем. Хлоритовый цемент является основным его компонентом и в среднем он составляет до 80-90\% цементирующего вещества. Участками наблюдаются контакты растворения или (и) кварцевый цемент регенерации. Иногда хлоритового цемента очень мало, основную роль в этом случае играет зернистый и регенерационный кварцевый цемент и в меньшей степени гидрослюдистый пленочно-поровый, облекая некоторые обломочные зерна и стенки некоторых пор. На отдельных интервалах отмечается обильный кальцитовый цемент порово-базального типа (в основании и туфогенных мелкозернистых песчаниках). Минеральные новообразования представлены гидрослюдами, хлоритом, кварцем, иногда титанистыми минералами, местами присутствуют вторичный кальцит, реже сидерит и пирит и крайне редко лейкоксен. Единично отмечается обрастание плагиоклаза альбитом. Обломки вулканического стекла на этой стадии литогенеза уже почти не сохраняются.

«Лисьи» песчаники (мощностью 11-28,5 м) светло-серые, преимущественно среднезернистые, в кровле тонко-мелкозернистые, однородные, неслоистые, с нечеткой горизонтальной (вверху) или перекрестно косой слоистостью за счет скоплений слюды и мельчайших растительных остатков (1-5\%) по наслоению. В основной среднезернистой своей части отмечаются присыпки мелкой фракции по наслоению, а в основании появляются крупнопсаммитовые разности песчаников и на контакте 
их с гравелитами наблюдается дресва алевролитов и сидерита. Среднезернистые песчаники $\mathrm{K}_{3} \mathrm{SK}_{4}$ относятся к полевошпат-кварцевым грауваккам. В обломочной их части отмечаются зерна кварца (30-35\%), полевых шпатов (23-36\%) и обломков пород: кварцитов (7-17\%), сланцев (7-22\%), эффузивов (8-17\%). Содержание слюд в них очень низкое (1-3\%). При сравнении их с «табачковыми» выявляется, что в «лисьих» песчаниках значительно выше содержание кварца и меньше обломков пород при почти таком же содержании полевых шпатов. Содержание литокластов в песчаниках $\mathrm{K}_{3} \mathrm{SK}_{4}$ не превышает 40-43\%, в то время как в «табачковых» их количество составляет 50-65\%. В мелкозернистых разностях $\mathrm{K}_{3} \mathrm{SK}_{4}$ отмечается значительное содержание слюд (15-25\%), среди которых наблюдаются лейстообразные пластинки свежего биотита пепловой природы. Кроме этого, в них встречаются пирокластической природы угловатые и призматические зерна свежих плагиоклазов, а также резко угловатые зерна кварца. Общее количество пирокластического материала составляет 20-25\% и вследствие этого песчаники можно считать туфогенными.

В разрезе «лисьих» песчаников отмечаются заметные колебания количественного содержания отдельных компонентов. Верхние их интервалы обогащены слюдами и хлоритом (до 15-25\%), тогда как в большей, средней части их количество минимальное (1-3\%), а в основании содержание слюд возрастает до 17-20\%. Для самых верхних и нижних горизонтов характерно более высокое содержание зерен эффузивных пород. В средней их части отмечается относительно повышенное содержание кварца, полевых шпатов и различных метакластов. В целом для песчаников $\mathrm{K}_{3} \mathrm{SK}_{4}$ характерно повышенное содержание обломков сланцев и эффузивов

Цемент сложный по составу и строению, местами кварцевый, регенерационный или кремнистогидрослюдистый, на отдельных интервалах кремнисто-серицитовый типа выполнения пор. Нередко отмечаются бесцементные контакты (примерно 20-25\% контактов) по поверхностям растворения. В них отмечаются разности на отдельных интервалах разреза с высоким (до 50\%) содержанием кварца в цементе. Хлоритовый цемент (5-10\%) появляется в нижней их части. Песчаники карбонатизированы на отдельных интервалах разреза - микрозернистый сидерит и более крупнокристаллический кальцит составляют от 10 до 15\%; в мелкозернистых слюдистых разностях содержание сидерита, образующего неправильные агрегаты около листочков биотита, достигает до 20\%. Минеральных новообразований в песчаниках немного - это кварц, гидрослюды, кальцит и сидерит. В туфогенных песчаниках минеральные новообразования значительно шире развиты, несмотря на то, что присутствуют те же самые аутигенные минералы - гидрослюды, хлорит, микрозернистый сидерит, а также иногда кварц и кальцит.

«Рубежные» песчаники (мощностью около 20м) светло-серые, средне-, реже крупнозернистые, в кровле мелкопсаммитовые, среднесортированные, с нечеткой косой и горизонтальной (вверху) слоистостью. В нижней трети их разреза они расслоены алеврито-тонкопесчаными прослоями, залегающими с размывом. Песчаники основной части принадлежат к полевошпат-кварцевым грауваккам с близким содержанием зерен кварца и полевых шпатов (около 24-25\% каждый). В них присутствуют обломки эффузивов кислого состава и кварцитов (примерно 15-16\%), в меньшей степени сланцев (около 9-10\%) и слюд (до10\%). Мелкозернистые их разности характеризуются повышенным содержанием слюд (биотита и мусковита) и хлорита в среднем до 20-22\%, полевых шпатов (до 30-35\%) и вулканокластов с микрофельзитовой основной массой кислых эффузивов (до 30\%) и пониженным содержанием зерен кварца и кварцитов. Содержание обломков пород: мета - (сланцев, кварцитов) и вулканокластов в среднем составляет около $30 \%$. Данные их разновидности относятся к кварц-полевошпатовым грауваккам. Цементы песчаников $\mathrm{K}_{9} \mathrm{SL}_{1}$ в среднем составляют от 20 до 30 \% породы, по составу они кремнисто-гидрослюдистые, кремнисто-хлорито-гидрослюдистые, хлорито-гидрослюдистые. Обычно гидрослюдистый материал составляет до 40\% цементирующего вещества и лишь на отдельных интервалах на него приходится до 65\% от общего объема цементирующего вещества. Содержание кварцевого материала в цементе, в том числе регенерационного кварца, колеблется в пределах 20-30\%.

Состав ассоциации глинистых минералов в основном биминеральный, представленный гидрослюдами и хлоритами: гидрослюды слабо гидротированные диоктаэдрические, хлориты нормально железисто-магнезиальные или с дефектом бруситового слоя $\left(\mathrm{d}_{\text {о01 }}=13,6-13,7 \mathrm{~A}^{0}\right.$ после прокаливания). Смешаннослойные образования (10-17А ) - ряда с незначительным содержанием разбухающей решетки обнаруживаются на начальном этапе и крайне редко (и лишь в мелкозернистых слюдистых разностях песчаников) на завершающем этапе позднего катагенеза. В более крупнозернистых 
разностях песчаников смешаннослойная фаза не была обнаружена, - их место занимает гидрослюда гидратированная и очень редко с каолинитом (песчаники $\mathrm{K}_{9} \mathrm{SL}_{1}$ ).

Таким образом, на стадии позднего катагенеза в моногенетических (баровых) песчаниках наблюдается структурное и более широкое минеральное разнообразие в их цементирующей массе, что обуславливает усложнение состава и типов цементов, по сравнению с постседиментационными их преобразованиями стадии раннего катагенеза. Усложнение состава и структуры цементов происходит в основном на завершающей стадии позднего катагенеза вследствие начавшегося широкого преобразования терригенных глинистых минералов и вулканогенного материала, часто присутствующего в составе песчаников. На начальном этапе позднего катагенеза (угли марки Г-Ж) в песчаниках преобладают гидрослюдистый или хлоритовый цементы пленочно-порового типа. На завершающем его этапе (угли марки К-OC), в одном случае (в основном для $\mathrm{K}_{9} \mathrm{SL}_{1}$ и отчасти $\mathrm{K}_{3} \mathrm{SK}_{4}$ ), встречаются кремнисто-гидрослюдистые, серицитово-кремнисто-гидрослюдистые, кварцевые с элементами регенерации, и реже кремнисто-серицитовые цементы, а в другом, - крустификационный хлоритовый цемент и местами поровый кварцевый (зернистый или/и регенерационный). Если изначально цемент был в основном хлоритовый, то его изменения происходят от пленочно-порового к крустификационному типу. В песчаниках с повышенным содержанием обломков слюд (биотита, мусковита и др.) и палеоэффузивов преимущественно среднего и отчасти кислого состава, увеличивается количество разновидностей цемента, и появляются несколько его типов: поровый и пленочно-поровый (нередко вместе с аутигенным кварцем) с незначительными участками развития регенерационно-кварцевого цемента и бесцементных контактов. В песчаниках с относительно малым содержанием обломков кварца и кварцитов (меньше $25 \%$ отмечается слабое развитие бесцементных контактов (2-3\%), в то время как в их разностях, характеризующихся повышенным содержанием этих обломков (до 50\%), на бесцементные контакты приходится, примерно, 20-25\% контактов. Встречаются прослои, где до 30-35\% всех контактов зерен без цемента - контакты между зернами извилистые конформные. Обычно бесцементные контакты наблюдаются в поле расположения слюдистых и глинистых сланцев, и лейстовидных пластинок биотита.

Среди аутигенных минералов отмечаются гидрослюда, хлорит, кварц, реже доломит и крайне редко альбит, лейкоксен и титанистые минералы; мелкозернистый сидерит и средне-крупнокристаллический кальцит. Сидерит и кальцит дают более разнообразные по строению и отчасти обильные цементы на отдельных интервалах разреза и на площади - порово-мозаичные, сгустковые и иногда базально-пойкилитовые цементы. В глинистой составляющей цементов песчаников, с одной стороны, наблюдаются новообразования: гидрослюды 2М (в основном, в «рубежных песчаниках), хлорита (особенно в «табачковых» песчаниках), а с другой, - почти полностью исчезают монтмориллонит, смешаннослойные образования смектит-хлоритового и смектит-каолинитового ряда. Смешаннослойные образования монтмориллонит-гидрослюдистого ряда с повышенным содержанием разбухающей фазы отмечаются в цементе на начальном этапе позднего катагенеза (угли марки Г-Ж), а на завершающем этапе этой стадии (угли марки К-ОС) они встречаются крайне редко и в их составе отмечается низкое содержание разбухающей фазы. Наибольшее разнообразие аутигенных минералов отмечается в туфогенных разностях песчаников (за счет преобразования пирокластического материала - слюд и отчасти акцессорных минералов группы пироксенов и амфибол, а также изменения обломков палеоэффузивов среднего состава). В них появляются анатаз, лейкоксен, реже доломит и увеличивается содержание тех минеральных новообразований, возникновение которых было зафиксировано на стадии раннего катагенеза и отчасти позднего диагенеза - гидрослюды, хлорита, кальцита и микрозернистого сидерита. Возникновение четко обособленного аутигенного кварца наблюдается на завершающем этапе начальной стадии позднего катагенеза (угли марки «Ж) в виде порового, а затем - регенерационно-порового (угли марки К-ОС) цемента.

Ранний метагенез (угли тощие - угли марки Т). Отложения каменской свиты, находящиеся на стадии преобразования раннего (начального) метагенеза (угли марки «Т»), распространены на юговосточной и восточной окраине Центрального Донбасса, тектонически приуроченной осевой части Донецкого прогиба (Центральный и отчасти Восточный Донбасс). Большая часть свиты (до известняка $\mathrm{K}_{6}$ ) уничтожена процессами денудации, но характер строения разреза и мощности примерно одинаковые, что и на других участках данной территории. Песчаники составляют до 65\% обломочных пород. Как правило, это мощные их горизонты (табачковые» песчаники до 30-33м, а «лисьи»песчаники до 24-25 м) или пласты до 2-3 м среди более тонких алевритовых пород. Начиная со стадии раннего 
метагенеза структурно-текстурные и минеральные новообразования в песчаниках происходят по-разному в зависимости от процентного содержания кварцевой составляющей и нестойких компонентов среди лито- и кристаллокластов в обломочной части.

В табачковых» песчаниках $\left(\mathrm{K}_{1} \mathrm{SK}_{2}\right)$ отмечается в основном хлоритовый цемент, где его содержание в среднем составляет до 80-85\% цементирующего вещества. Участками наблюдаются контакты растворения или (и) кварцевый цемент регенерации. На отдельных интервалах с малым содержанием «цементирующего» хлорита наблюдается зернистый и регенерационный кварцевый цемент и в меньшей степени гидрослюдистый пленочно-поровый, «крустификационно-шиповидно» облекая некоторые обломочные зерна и стенки некоторых пор. Иногда хлоритового цемента очень мало и основную роль в этом случае играет базальный крупнокристаллический кальцитовый цемент.

Состав аутигенных минералов почти тот же самый, что и в аналогичных песчаниках из зоны глубинного катагенеза (зона развития углей К-ОС), только их проявления более существенны. Минеральные новообразования представлены хлоритами, гидрослюдами, кварцем, иногда титанистыми минералами, местами присутствуют вторичный кальцит, реже сидерит и пирит и крайне редко лейкоксен.

В «лисьих» песчаниках $\left(\mathrm{K}_{3} \mathrm{SK}_{4}\right)$ цементы сложные по строению и смешанные по составу. В них наблюдаются пленочно-поровый тип, с довольно значительными участками бесцементных контактов (иногда до 35-48\% общего количества контактов). На отдельных интервалах обильные цементы дают карбонаты - порово-мозаичные, сгустковые и иногда базальные их типы. Обычно они представлены спаритом, в редких случаях - мелкозернистым сидеритом и крайне редко доломитом.

Минеральные новообразования многочисленны. Среди них хлориты и гидрослюды являются преобладающими, и они часто дают крупные веерообразные сростки. Наиболее широко распространены аутигенные: кварц, сидерит, кальцит и реже доломит, а также пирит, содержание которого составляет обычно 1-3\% в тонко- и мелкозернистых песчаниках. Часто пирит концентрируется по наслоению около мелких растительных остатков нередко вместе с лейкоксеном, количество которого в некоторых случаях может достигать $10 \%$. В туфогенных разностях отмечаются анатаз, редко апатит и иголочки рутила. В ряде случаев в песчаниках наблюдаются гематит.

Поздний метагенез (угли антроцитовые - угли марки А). Отложения каменской свиты, вмещающие угли марки «А», распространены на территории Восточного Донбасса и тектонически приурочены к наиболее прогнутой осевой части Донецкого прогиба, сложенного сильно измененными и дислоцированными толщами, преобразованными до стадии позднего метагенеза. Отличительными чертами разреза каменской свиты является большая мощность разреза свиты (около 900 м) и увеличение в разрезе роли песчаников (до 40 \%), в основном за счет повышения мощности основных горизонтов песчаников $\left(\mathrm{K}_{1} \mathrm{SK}_{2}, \mathrm{~K}_{3} \mathrm{SK}_{4}\right.$ и $\left.\mathrm{K}_{9} \mathrm{SL}_{1}\right)$.

В «рубежных» песчаниках поздней стадии метагенеза отмечаются значительные изменения в обломочной их части, связанные с растворением нестойких компонентов - полевых шпатов и эффузивов и отсутствия биотита. Это способствует возрастанию кварцевой составляющей за счет обломочного кварца и метакластов, преимущественно кварцевого состава: кварцитов и различных слюдистокварцевых сланцев. Среди песчаников отсутствуют кварц-полевошпатовые разности граувакк, а некоторые их разности являются мезомиктовыми и их можно отнести к субграуваккам. Цементы сложные по составу и строению, преобладает кварцевый цемент регенерации, а также зернистый; в меньшей степени развиты «шиповидно-поровый» кварцево-серицитовый цемент и цементация растворения с образованием конформных и инкорпорационных структур. На некоторых интервалах песчаники послойно рассланцованы, с широким развитием аутигенных слюд - гюмбелита [Волкова и др., 1979] и лейкоксена. Отдельные их прослои характеризуются обильной вторичной карбонатизацией. В крупногрубозернистых разностях $\mathrm{K}_{9} \mathrm{SL}_{1}$ цемент преимущественно регенерационный кварцевый, очень редко на небольших участках наблюдается тончайшая регенерационная кайма аутигенного альбита вокруг обломков плагиоклазов среднего состава. Велика в них роль бесцементных контактов с образованием конформных, реже инкорпорационных структур. Широко развит кварцевый регенерационный, в меньшей степени кремнисто-хлоритовый цементы. Значительно распространены микростилолитовые поверхности. Из минеральных новообразований присутствуют в относительно большом количестве кварц, серицит, гюмбелит, реже мусковит, кальцит, сидерит и крайне редко хлориты и альбит.

В «лисьих» песчаниках $\left(\mathrm{K}_{3} \mathrm{SK}_{4}\right)$ широко развиты бесцементные контакты, особенно в крупнозернистых их разностях, где на их долю приходится до 50\%, в то время как в мелкопсаммитовых они составляют все- 
го около 20\%. Часто преобладают кварцевые регенерационные или (и) кварцево-серицитовые цементы, очень небольшую долю в цементе играет хлорит. На отдельных интервалах отмечаются вторичные карбонатные цементы, слагающие местами до 10-20\% породы. Отдельные микрозернистые их разности с обилием слюды по слоистости и относящиеся к туфогенным песчаникам, претерпевают значительные преобразования. Агрегаты сидерита прорастают мельчайшими чешуйками хлорита и гидрослюд, становятся менее прозрачными, вместо биотита присутствуют овальные и веретенообразные, часто с пережимами хлоритовые и мусковит-хлоритовые сростки. Такие же сростки и микролинзочки концентрируются около растительных остатков, наиболее часто они представлены новообразованиями хлорита. На участках с малым содержанием слюдистого материала отмечается серицито-кварцевые и кварцевые регенерационные цементы. Из минеральных новообразований наблюдаются серицит, гюмбелит и мусковит, а также хлориты, кварц, сидерит, кальцит и крайне редко титанистые минералы (анатаз, лейкоксен).

В «табачковых» песчаниках $\left(\mathrm{K}_{1} \mathrm{SK}_{2}\right)$ преобладает цементация растворения (примерно половина контактов) с образованием конформных, реже инкорпорационных структур. Широко развиты кварцевый регенерационный, в меньшей степени кремнисто-хлоритовый цементы. Значительно распространены микростилолитовые поверхности. Существенно преобразованы туфогенные разности песчаников - формируются мусковит-хлоритовые веретенообразные микролинзочки и сростки, по мелкозернистым (ранее глинистым?) сидеритам широко развиваются чешуйки аутигенного хлорита. На некоторых интервалах наблюдается формирование оторочек гюмбелита (слюда группы мусковита), хлорита (иногда в прорастании с кварцем) около растительных остатков, а также мусковитовых агрегатов по микростилолитовым поверхностям и в порах.

Таким образом, в песчаниках поздней стадии метагенеза отмечаются значительные изменения, связанные с растворением нестойких компонентов - полевых шпатов и эффузивов и почти полным преобразованием биотита. Песчаники становятся более кварцевыми по составу за счет возрастания роли кварцевых зерен и обломков метаморфических пород, преимущественно кварцевого состава: кварцитов и различных слюдисто-кварцевых сланцев. Вследствие этого среди них почти полностью отсутствуют кварц-полевошпатовые разности граувакк, а сами песчаники становятся олиго-мезомиктовыми и их можно отнести к субграуваккам. Существенно преобразованы туфогенные разности песчаников - формируются мусковит-хлоритовые веретенообразные микролинзочки и сростки, по мелкозернистым (ранее глинистым?) сидеритам широко развиваются чешуйки аутигенного хлорита. На некоторых интервалах наблюдается формирование оторочек гюмбелита, хлорита (иногда в прорастании с кварцем) около растительных остатков, а также мусковитовых агрегатов по микростилолитовым поверхностям и в порах.

1. Викулов А.Г., Седаева К.М., Викулова Е.А. Пирит угленосных отложений Донбасса. - М.: Изд-во Московского ун-та, 2002. - $171 \mathrm{c}$.

2. Вишневская В.С., Седаева К.М. Особенности осадконакопления в раннем - среднем карбоне на юге Восточно-Европейской платформы // Литол. и полез. ископ. - 2000. - № 5. - С. 512-522.

3. Волкова А.Н., Седаева К.М. Литогенетические основы типизации обломочных и карбонатных пород среднего карбона Донбасса // Бюлл. МОИП.Отд. геол. - 1984. - Т. 59.- Вып. 1. - С. 74-86.

4. Граувакки (отв. ред. Шутов В.Д.). - М.: Наука, 1972. 127 с. - (Тр. ГИН АН СССР; Вып. 238).

5. Жемчужников Ю.А., Яблоков В.С. и др. Строение и условие накопления основных угленосных свит и угольных пластов среднего карбона Донецкого бассейна. Изд-во АН СССР, Москва: 1959. - 332 с. - (Тр. ГИН АН СССР; Вып. 15; Ч. 1).

6. Жемчужников Ю.А., Яблоков В.С. и др. Строение и ус- ловие накопления основных угленосных свит и угольных пластов среднего карбона Донецкого бассейна. М.: Изд-во АН СССР, 1960. - 347 с. - (Тр. ГИН АН СССР; Вып. 15; Ч. 2).

7. Крашенинников Г.Ф. Угленосные формации Большого Донбасса // Сб. ст. - М.: Наука, 1983. - С. 14-22.

8. Крашенинников Г.Ф., Волкова А.Н., Иванова Н.В., Рекшинская Л.Г., Седаева К.М. Влияние генетических особенностей на формирование физико-механических свойств пород среднего карбона Донецкого бассейна // Вестн. МГУ. Сер. 4. Геология. - 1984. - № 2. C. 37-52.

9. Логвиненко Н.В. Литология и палеогеография продуктивной толщи донецкого карбона. - Харьков: Издво Харьковского ун-та, 1953. - 459 с.

10. Логвиненко Н.В Постдиагенетические изменения осадочных пород. - Ленинград: Наука, 1968. - 92 с.

11. Петтиджон Ф., Поттер П., Сивер Р. Пески и песчаники. - М.: Мир, 1976. - 535 с.

Geological Department of Moscaw State University, Moscaw, Russia.

Геологический факультет МГУ им. М.В. Ломоносова, г. Москва, Россия 